\title{
自然環境保全基礎調査植生調査データを用いた森林群集・ 群落の潜在的分布域の地図化
}

\author{
鎌田 磨人 ${ }^{*}$. 安東 純平 $^{2} \cdot$ 染矢 貴 $^{3} \cdot$ 浅井 樹 $^{3}$ \\ 1 徳島大学大学院ソシオテクノサイエンス研究部 干 770-8506 徳島市南常三島町 2-1 \\ 2 徳島大学工学部建設工学科 $\bar{T} 770-8506$ 徳島市南常三島町 2-1 \\ 3 アジア航測 [ 株 ] 環境部環境デザイン課干215-0004＼cjkstart神奈川県川崎市麻生区万福寺 1-2-2
}

\section{Mapping potential habitats for 53 forest communities: exemplified usage of data collected through national vegetation survey \\ Mahito Kamada $^{1^{*}}$, Junpei Ando ${ }^{2}$, Takashi Someya ${ }^{3}$ and Miki Asai ${ }^{3}$}

\author{
${ }^{1}$ Division of Ecosystem Design, Institute of Technology and Science, Tokushima University, 2-1 Minami- \\ Josanjima, Tokushima 770-8506, Japan \\ ${ }^{2}$ Department of Civil and Environmental Engineering, Tokushima University, 2-1 Minami-Josanjima, \\ Tokushima 770-8506, Japan \\ ${ }^{3}$ Asia Air Survey Co., Ltd., 1-2-2 Manpukuji, Asao-ku, Kawasaki, Kanagawa 215-0004, Japan
}

Key Words: Natural environmental information GIS, Digital national land information, Maxent (Maximum Entropy Model), Species distribution model, Environmental factors

要旨 : 自然環境保全基礎調査の第 6 回（1999～2004 年)・第 7 回（2005～2009 年）植生調査では，11572 地点で現地調査が行われ， それぞれの地点の植生に対して統一凡例が付与されている。この中から 20 地点以上で分布が確認されている 53 の森林群集・群落の 空間情報を得た. 次に, $1 \mathrm{~km}$ メッシュで入手できるWI (温量指数), CI (寒さの指数), 年降水量, 最深積雪量, 地質区分, 最大傾 斜角を説明変数として Maxent 解析を行い, それら群集・群落の分布決定要因を抽出した上で, 潜在的分布域地図を描いた. そして, 国によって進められ蓄積されてきている植生調査データの活用に係る展望と必要性について，意見を述べた.

キーワード：自然環境情報 GIS，国土数值情報，Maxent，生物分布モデル，環境要因

はじめに

我が国では，自然環境保全法に基づく自然環境保 全基礎調査が，環境省によって行われてきている. 「緑の国勢調査」とも呼ばれるこの調査は，「全国的 な観点から我が国における自然環境の現況及び改変 状況を把握し，自然環境保全の施策を推進するため の基礎資料を整備する」ことが目的となっている (http://www.biodic.go.jp/kiso/fnd_f.html). 多岐にわた る調査項目のうち「植生調査」は，40 年以上に渡っ て継続的に実施されており，1973 年度（第 1 回植生

*連絡先 : kamada@ce.tokushima-u.ac.jp 受付 : 2014 年 11 月 21 日/受理 : 2014 年 11 月 26 日
調查）には $1 / 200,000 ， 1978 １ 986$ 年度（第 $2 \cdot 3$ 回） には $1 / 50,000$ の植生図が日本全土にわたって整備さ れた. 1989〜 1998 年度（第 $4 \cdot 5$ 回）は，人工衛星 データを活用した第 $2 \cdot 3$ 回の植生図の修正にとど まったが，1999年度以降（第 6 回〜）は，1/25,000 植生図の作成が新たに進められている（http://www. vegetation.biodic.go.jp/chosa/index.html)。1975 年度以 降に作成された植生図は全て GIS 化され, 誰もがダ ウンロードして利用することができるようになって いる (http://www.biodic.go.jp/trialSystem/top.html).

「植生調査」における植生図の作成は，植物社会学 的手法（ブラウン-ブランケ 1964 ; 宮脇ほか 1994） に基づく現地調査と空中写真もしくは衛星画像の判 読をもとに行われている. 1999 年度以降の「植生調 
查」では, 日本は 8 つのブロックに分けられ, それ ぞれのブロックに調査結果等について助言を与える 専門家からなる「ブロック調査会議」が設置されて いる. 調査受託者は, 調查地域において土地利用を 除く全ての植生型について 2 地点以上，広域に分布 する二次林の植生型については 1/25,000 地形図 1 図 幅に対して 2 地点以上で調查を行うことになってい て，それぞれの地点では，その位置座標と階層別の 被度・群度が種ごとに記録される. その後, 表操作 等をとおして群集・群落が区分され，ブロック調査 会議での検討を経て植生図凡例として提案される. 日本全体として統一した凡例体系を整備していくた めの機関として「凡例検討部会」が設置されていて, それぞれのブロックから提案された植生凡例はそこ で検討され（http://www.vegetation.jp/6thgaiyou/taisei. html), 全国統一凡例が決定される（http://www. vegetation.jp/hanrei/index.html) .

こうした調查・作業にともなって, 第 7 回植生調 查終了時点（2009 年度）には，11572 地点に及ぶ種 や群集・群落の分布位置データが得られている。し かし残念ながら，これらの情報は一般には公開され ておらず，それら膨大なデータは十分に活用されな いまま埋蔵されている。希少種や絶滅危惧種の分布 情報を含むこと，種の同定精度が一様でないこと， 一部で種名の統一が図られておらずシノニムが混在 していること等がその理由であるが，そうした課題・ 制約を踏まえつつ, データ活用のあり方を提示して いく必要がある。

植生学や生態学において, 植物群集 ・群落の分布 境界や遷移系列上の位置づけ，そして，それらを決 定づける環境要因の究明は，最も基本的な問いの一 つである。近年は生物の分布を環境要因と関連付け て説明し, 生息・生育可能域を地図化して示寸空間 モデルが発展してきている（例えば, Scott et al. 2002 ; Franklin 2010 ; Arakida et al. 2011). こうした 手法を適用しつつ, 統一的な手法で収集され凡例が 付与された「植生調查」データを環境要因と関連付 けて解析し, 群集・群落が成立し得る空間範囲を示 寸ことが可能となっている（染矢ほか 2010）。

本報告では,「植生調査」データと国土数值情報か ら, 日本の主要植生である森林群集・群落の分布決 定要因を推定する。そして，それらの潜在的分布域 を描いた上で, 空間的重複度による群集・群落類型 を示す．最後に，これらを基に「植生調査」データ の活用可能性について検討する.

\section{方法}

\section{1. 利用データ}

（1）植物群集・群落の分布デー夕

自然環境保全基礎調査第 6 回（1999～2004 年度) • 第 7 回（2005 2009 年度）の植生調査資料から, 20 地点以上で分布が確認されている 53 の森林群集・ 群落を抽出した (表 2 参照)。そして, 各々の群集・ 群落の分布が確認された位置をポイントデータと し, GIS に格納した. 使用した地点総数は 4443 となっ た.

\section{(2) 環境要因}

広域的にみた場合, 森林群集・群落の分布を決定 づける主要な要因は，気候，地質，地形だと言われ ている（例えば, 山中 1979 ; 宮脇ほか 1994 ; 菊池 2001)。ここでは, それらをWI (温量指数), CI (寒 さの指数), 年降水量, 最深積雪量, 地質区分, 最大 傾斜角を用いて表現することとした.

気候データは，1971〜2000 年の観測平均值が $1 \mathrm{~km}$ メッシュ（3 次メッシュ）に格納された「メッシュ気 候值 2000 (気象庁)」を用いた，WIおよびCIについ ては月平均気温から $1 \mathrm{~km}$ メッシュごとに求めた值を, 年降水量および最深積雪量はメッシュ気候值 2000 の 1 $\mathrm{km}$ メッシュ值を GIS に格納した。 なお，現在は 1980 〜 2010 年の観測平均值をダウンロードすることができ る (http://nlftp.mlit.go.jp/ksj/gml/datalist/KsjTmplt-G02. $\mathrm{html})$.

地質データは, 「50万分の 1 土地分類基本調査, 表層地質図（国土交通省）」を用いた（http://nrbwww.mlit.go.jp/kokjo/inspect/landclassification/ download/index.html). 本地質図で使用されている凡 例を統合して 8 つの地質区分とし（表 1), $1 \mathrm{~km}$ メッ シュ内の個々の面積を集計して GIS に格納した.

最大傾斜角は, 国土数值情報の「標高・傾斜度メッ シュ」を用い, $1 \mathrm{~km}$ メッシュの最大傾斜角を GIS に 格納した（http://nlftp.mlit.go.jp/ksj/jpgis/datalist/KsjTmpltG04-b.html).

\section{2. 森林群集・群落の潜在的分布域の推定}

沖縄県を除く日本全域について，1 kmメッシュを 用いた解析を行なった。 寸なわち, 各々の森林群集・ 群落の分布位置を $1 \mathrm{~km}$ メッシュに統合した上で環 境要因と関連付け, Maximum Entropy Model（Maxent; Phillips et al. 2006）を用いて, 群集・群落の分布を 説明する空間モデルを構築した. Maxent は, 在デー 
表 1. 地質図の凡例統合

\begin{tabular}{|c|c|c|c|}
\hline 1/50万表層地質図凡例 & 統合凡例 & 1/50万表層地質図凡例 & 統合凡例 \\
\hline $\begin{array}{l}\text { 第四紀 堆積岩類 } \\
\text { 砂礫·粘土 }\end{array}$ & \multirow{5}{*}{ 1. 第四紀 堆積岩類 } & \begin{tabular}{|l|} 
火成岩類 火山岩類 \\
流紋岩類
\end{tabular} & \multirow{3}{*}{ 5. 火山岩類 } \\
\hline $\begin{array}{l}\text { 第四紀 堆積岩類 } \\
\text { 火山灰·ローム }\end{array}$ & & \begin{tabular}{|l} 
火成岩類 火山岩類 \\
安山岩類
\end{tabular} & \\
\hline $\begin{array}{l}\text { 第四紀 堆積岩類 } \\
\text { 砂丘砂 }\end{array}$ & & \begin{tabular}{|l} 
火成岩類 火山岩類 \\
玄武岩類
\end{tabular} & \\
\hline $\begin{array}{l}\text { 第四紀 堆積岩類 } \\
\text { 溶結凝灰岩 }\end{array}$ & & \begin{tabular}{|l} 
火成岩類 深成岩類 \\
花崗岩類
\end{tabular} & \multirow{4}{*}{ 6. 深成岩類 1} \\
\hline $\begin{array}{l}\text { 第四紀 堆積岩類 } \\
\text { 洪積砂礫 } \\
\text { (段丘堆積物を含む) }\end{array}$ & & \begin{tabular}{|l} 
火成岩類 深成岩類 \\
斑れい岩·輝緑岩
\end{tabular} & \\
\hline $\begin{array}{l}\text { 新第三紀 堆積岩類 } \\
\text { 砂岩·泥岩·礫岩など } \\
\text { (緑色凝灰岩) }\end{array}$ & \multirow{3}{*}{ 2. 第三紀 堆積岩類 } & \begin{tabular}{|l} 
火成岩類 深成岩類 \\
蛇紋岩·檄欖岩
\end{tabular} & \\
\hline 古第三紀 堆積岩類 & & & \\
\hline 砂岩·泥岩·磷岩など & & \begin{tabular}{|l} 
変成岩類 \\
結晶片岩類
\end{tabular} & \multirow{2}{*}{ 7. 変成岩類 2} \\
\hline $\begin{array}{l}\text { 中生代 堆積岩類 } \\
\text { 砂岩·頁岩·磷岩など }\end{array}$ & 3. 中生代 堆積岩類 & \begin{tabular}{|l} 
変成岩類 \\
片麻岩類
\end{tabular} & \\
\hline $\begin{array}{l}\text { 古生代 堆積岩類 } \\
\text { 石灰岩類 }\end{array}$ & \multirow{3}{*}{ 4. 古生代 堆積岩類 } & 埋立地 & \multirow{3}{*}{ 8. その他 } \\
\hline 古生代 堆積岩類 & & & \\
\hline $\begin{array}{l}\text { 粘板岩·砂岩·チャート· } \\
\text { シャールイダ輝緑凝灰岩) }\end{array}$ & & 水域 & \\
\hline
\end{tabular}

タのみを用いる場合や，標本数が少ない場合のモデ ル構築に有効だとされる（Elith et al. 2006; Hernandez et al. 2006)．なお，沖縄県を対象外とした のは, 「50 万分の 1 土地分類基本調查，表層地質図」 に沖縄県のデータが含まれていないという制約によ る.

得られたモデルの適合度は, [感度］と［1-特異度］ から得られる ROC (Receiver Operating Characteristic) 曲線から AUC（Area Under Curve）を算出すること で評価した（Swet 1988 ; Fielding and Bell 1997). AUC は 0.5 〜 の範囲の值をとり， 1 に近づくほど モデルで推定される在・不在の領域が重ならないこ と，すなわち適合度が高いことを示す。一般に，モ デルで推定される在・不在領域は重なりあう部分を 持つため, 在・不在を分かつ值（カットオフ值）を 設定し，それぞれの領域を区分する必要がある。こ こでは，モデル精度を感度と特異度の合計值で評価 することとし，それが最も大きくところをカットオ フ值とした（Manel et al. 2001 ; Lui et al. 2013). そし て, 得られた空間モデルを用いて, 53 の森林群集・ 群落それぞれの潜在的分布域地図を描いた。

一連の空間解析作業にはArc GIS 9.3.1および Spatial Analyst (ESRI) と, Maxent (http://www.cs. princeton.edu/ schapire/maxent/）を使用した。

\section{3. 空間重複度を用いた森林群集・群落の類型化}

（1）空間重複度の算出

各々の森林群集・群落について得られた潜在的分 布域地図をオーバーレイし，2つの群集・群落間で 重なりあう領域を抽出した。 そして, それぞれの群 集・群落について，他の全ての群集・群落との空間 重複度を式 1 により求めた。組み合わせ数が 2756(53 $\times 52 ）$ となる空間重複度の算出には，R-2.11.1を用 いた.

空間重複度（\%）＝任意の他の群集 - 群落の潜在 的分布域と重なっている面積／当該群集・群落の 潜在的分布域面積 $\times 100$ (式 1)

\section{(2) 森林群集 - 群落の類型化}

上記により得られた空間重複度行列を用いて，群 平均法によるクラスター分析を行い, 空間分布の重 なり具合からみた森林群集・群落類型を行なった。 そして, Maxent 解析で得られた個々の環境要因の寄 与率と反応曲線から，群集・群落間のニッチの異同 を検討した。 クラスター分析には PRIMER Ver.6 を 使用した。

\section{結果と考察}

\section{1. 群集・群落の潜在的分布域とそれを規定する環境} 要因

表 2 に，空間重複度を用いたクラスター解析によ 
る森林群集・群落の類型と, Maxent 解析によって得 られたモデルの AUC, カットオフ值, モデルへの累 積寄与率が 90\%を超えるまでの環境要因を示した。 AUC は $0.872 \sim 0.997$ の範囲であり, 全てのモデル について適合度が高かったことから（Swets 1988）, 対象とした 53 の群集・群落の潜在的分布域を求める ことが可能だと判断した. そして, カットオフ值を
超える分布確率を持つ領域を潜在的分布域とする地 図を作成した（図 1).

森林群集・群落は $\mathrm{A} \sim \mathrm{D}$ からなるグループと $\mathrm{E} ・$ Fからなるグループに大別され，前者のほとんどは ブナクラス域の, 後者はヤブツバキクラス域の群集・ 群落であった（表 2)．この 2 つのグループの分布の 違いを決定づける環境要因は, 主にCI と最深積雪量
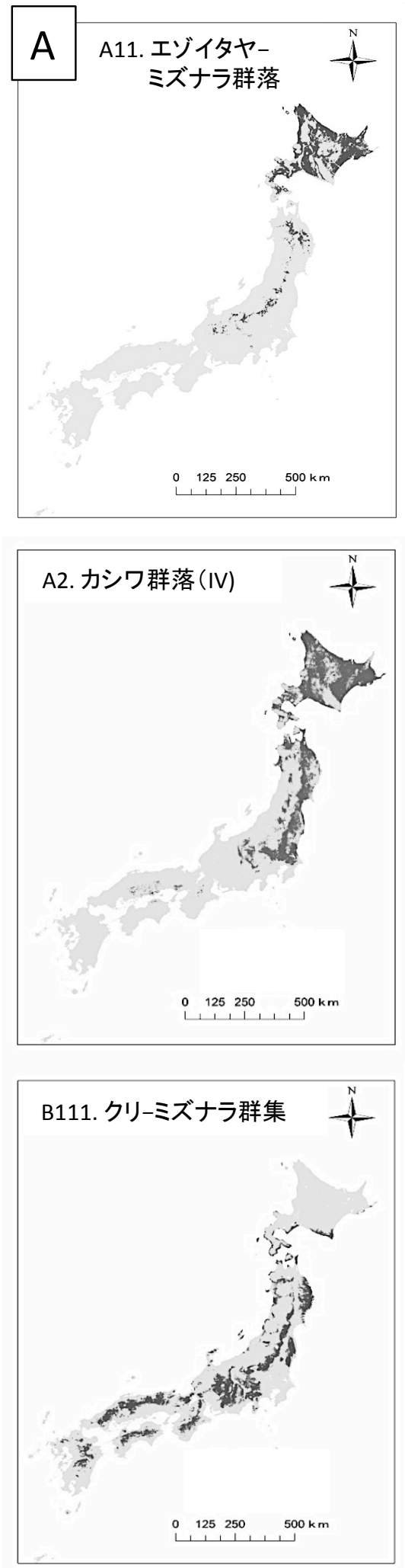
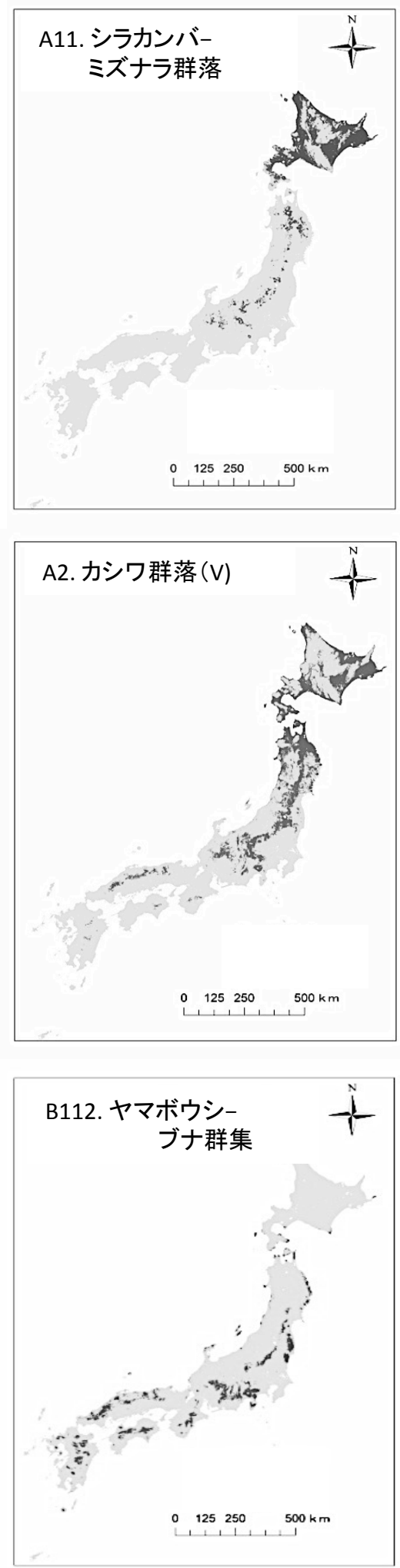

図 1 . 森林群集・群落の潜在的分布域地図
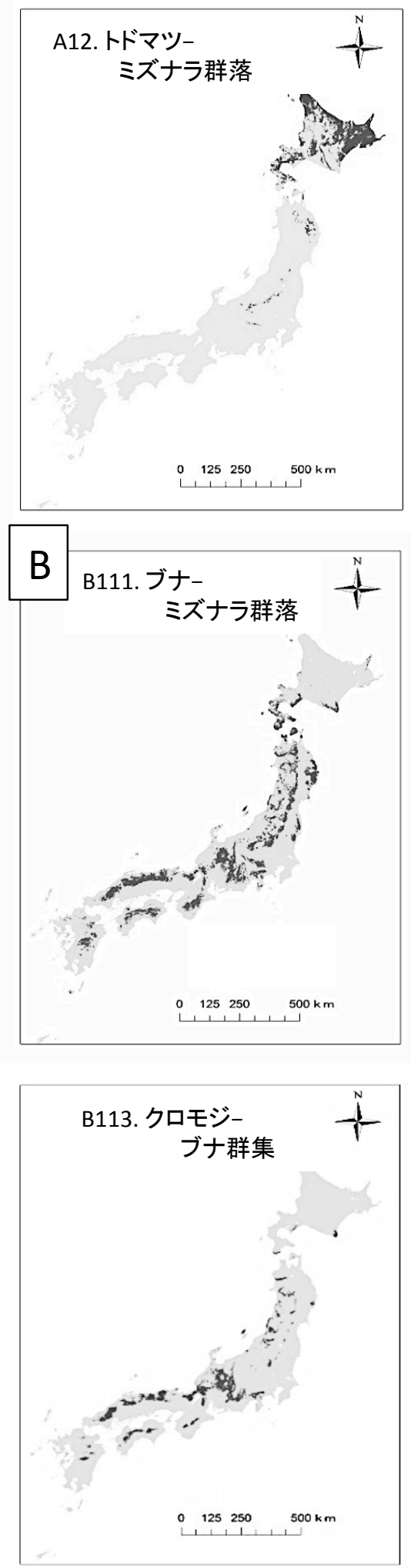

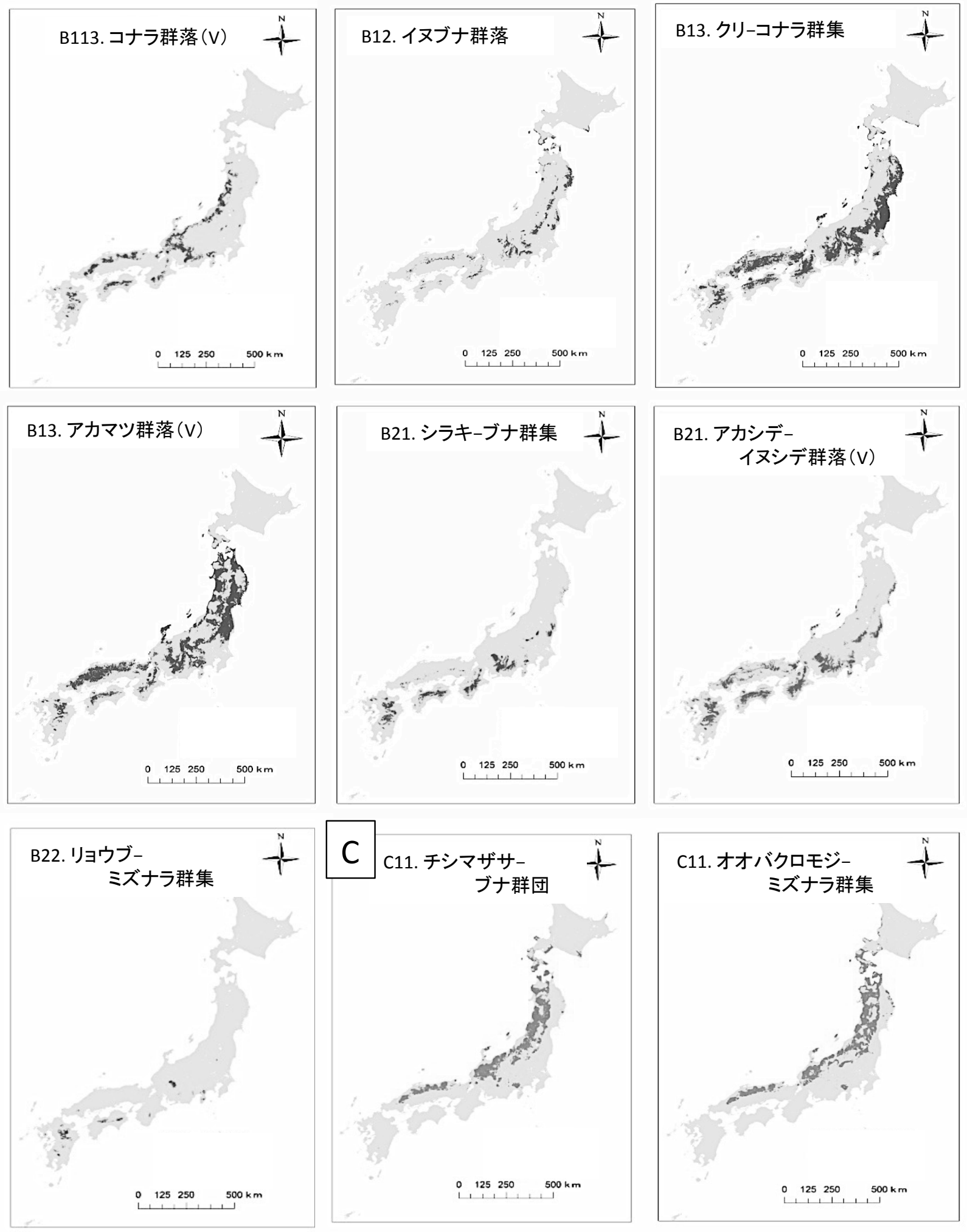

図1. 続き 

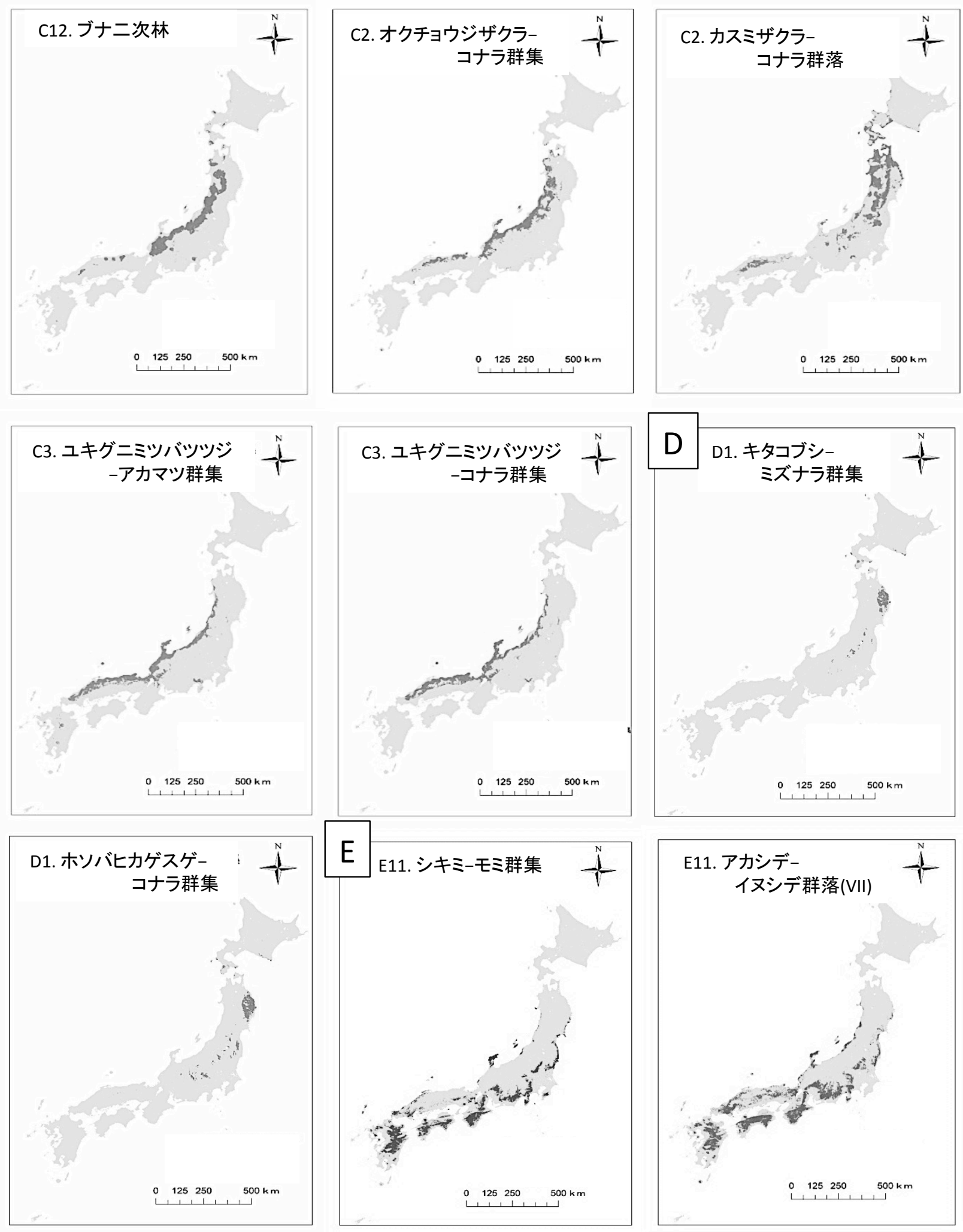

図 1. 続き 

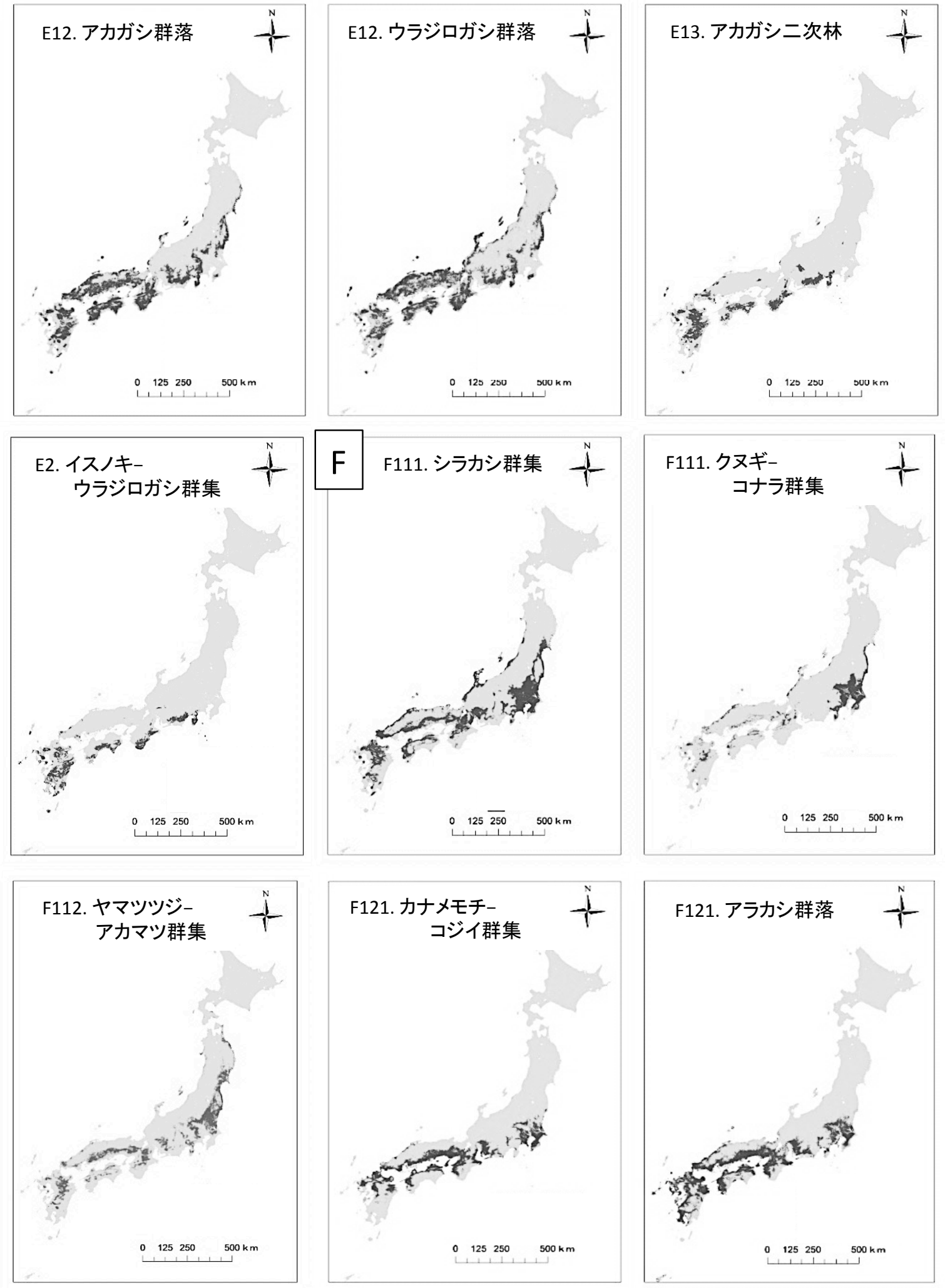

図1. 続き 

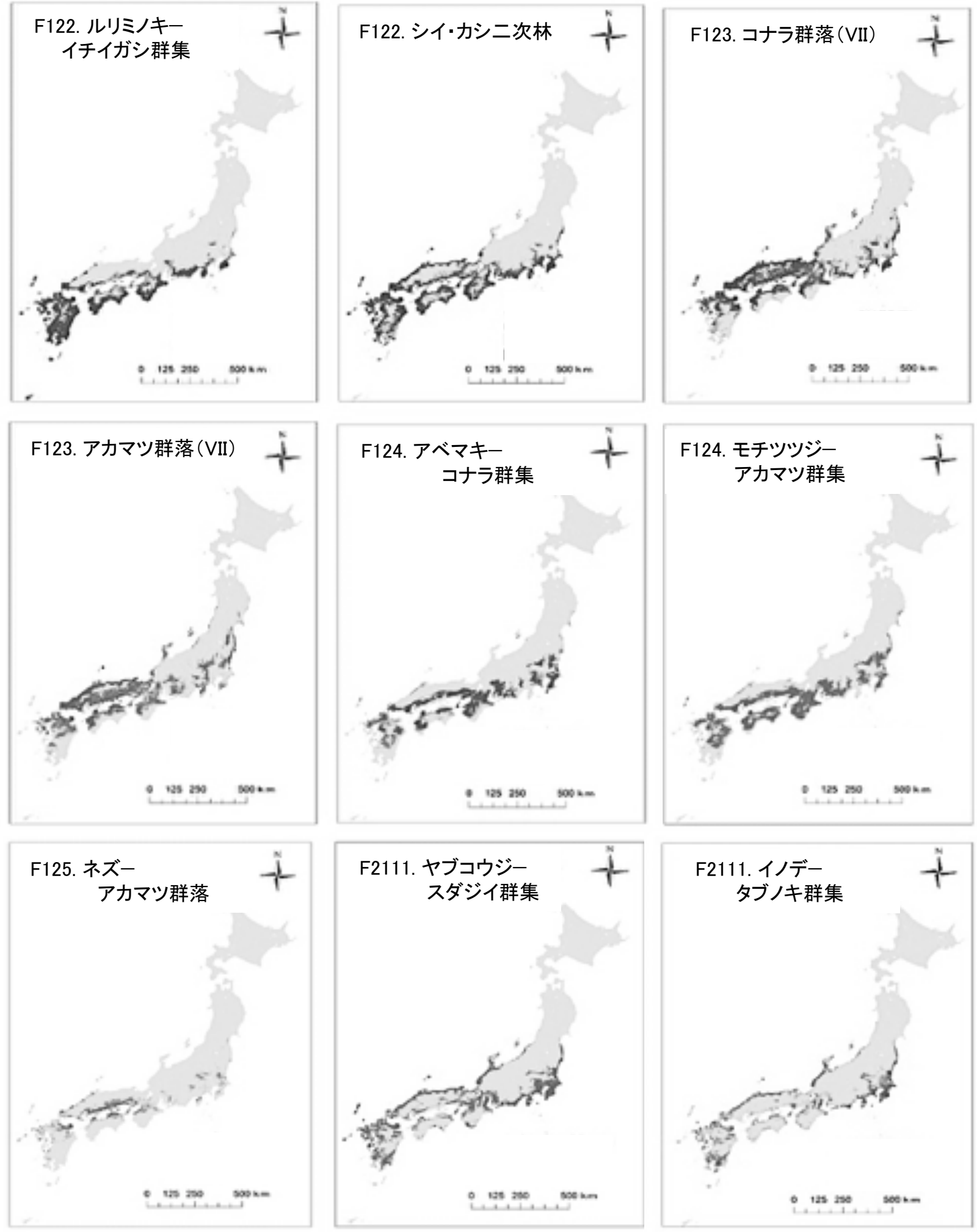

図 1. 続き 

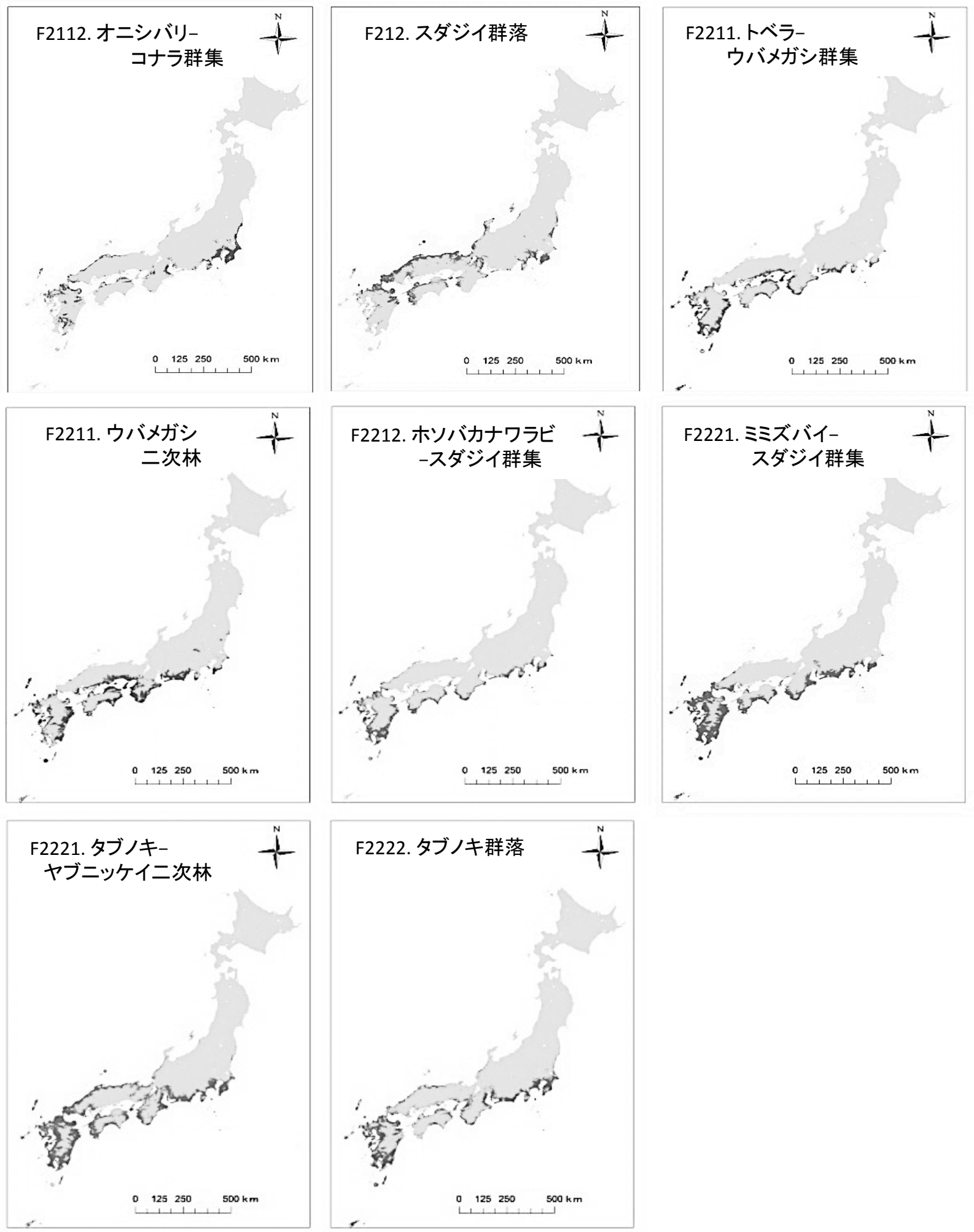

図 1. 続き 
で, $\mathrm{A} \sim \mathrm{D}$ のグルプの分布確率は, $\mathrm{CI}$ および最深積 雪量に対してへ型の関係を示す傾向があった。一方, $\mathrm{E} ・ \mathrm{~F}$ での分布確率は, CI および最深積雪量が小さ い地域で最も高くなり，值の増加につれて低くなる 傾向を示した.

$\mathrm{A}$ は北海道と東北地方に潜在的分布の中心を持つ
グループであった（図 1-A)。そのうち, A1 は北海 道に潜在的分布域の中心がある。自然植生であるエ ゾイタヤーミズナラ群落とトドマツーミズナラ群落 は，第三期および中生代の堆積岩類からなる地域に 分布しているが, 前者は最深積雪量が $80 \sim 170 \mathrm{~cm}$ 程度の地域で分布確率が最大となり, 後者は降水量

表 2. 空間重複度を用いたクラスター解析による森林群集・群落の類型, および, Maxent 解析によって得られた モデルの AUC, カットオフ值, モデルへの累積寄与率が $90 \%$ を超えるまでの環境要因. 気候要因に付し た+は変量の増加につれて分布確率が増加すること, - は減少すること, ○は増加した後に減少すること を示す. 地質に付した数字は, 表 1 で示した地質凡例に対応し, その地質を持つ地域で分布確率が増加す ることを示す。

\begin{tabular}{|c|c|c|c|c|c|c|c|c|c|c|c|c|c|c|c|c|c|c|}
\hline & \multirow{2}{*}{\multicolumn{3}{|c|}{ 類型 }} & \multirow{2}{*}{\multicolumn{2}{|c|}{ 森林群集·群落(植生図凡例) }} & \multirow{3}{*}{$\begin{array}{c}\begin{array}{c}\text { 地点 } \\
\text { 数 }\end{array} \\
36\end{array}$} & \multirow{3}{*}{$\begin{array}{c}\text { AUC } \\
0.954\end{array}$} & \multirow{3}{*}{$\begin{array}{c}\text { カット } \\
\text { オフ值 } \\
0.337\end{array}$} & \multicolumn{10}{|c|}{ 環境要因の順位と寄与率 } \\
\hline & & & & & & & & & 1 & & 2 & & 3 & & 4 & & 5 & \\
\hline \multirow{5}{*}{ A } & \multirow{2}{*}{$\left.1\right|^{1}$} & \multirow{2}{*}{\multicolumn{2}{|c|}{1}} & |エゾイタヤーミズナラ群落 & IV & & & & $\overline{\mathrm{CI}(\cap)}$ & 80.0 & 積雪 $(n)$ & 8.1 & 地質 $(2,3)$ & 7.4 & & & & \\
\hline & & & & シラカンバーミズナラ群落 & $\mathrm{v}$ & 41 & 0.958 & 0.226 & CI $(n)$ & 75.7 & 地質 $(1,2)$ & 12.1 & 傾斜 $(n)$ & 7.1 & & & & \\
\hline & \multicolumn{3}{|c|}{2} & トドマツーミズナラ群落 & IV & 41 & 0.955 & 0.307 & $\mathrm{CI}(\cap)$ & 73.1 & 地質 $(2,3)$ & 11.2 & 降水 (-) & 7.6 & & & & \\
\hline & \multirow{2}{*}{\multicolumn{3}{|c|}{2}} & カシワ群落(IV) & IV & 28 & 0.916 & 0.209 & 降水 $(-)$ & 51.6 & 傾斜 (-) & 20.6 & WI $(-)$ & 17.3 & 地質 (1) & 10.5 & & \\
\hline & & & & カシワ群落(V) & $\mathrm{v}$ & 26 & 0.901 & 0.289 & $\mathrm{CI}(\cap)$ & 47.1 & 地質 (1) & 24.8 & 積雪 $(n)$ & 10.9 & 傾斜 (-) & 6.6 & 降水 $(-)$ & 6.3 \\
\hline \multirow{11}{*}{ B } & & & 1 & ブナーミズナラ群落 & $\mathrm{V}$ & 104 & 0.943 & 0.270 & WI $(\cap)$ & 35.2 & 降水 (+) & 22.5 & $\mathrm{CI}(\cap)$ & 12.8 & 傾斜 (+) & 10.9 & \begin{tabular}{|l|} 
積雪 $(+)$ \\
\end{tabular} & 9.8 \\
\hline & & & 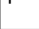 & クリーミズナラ群集 & $\mathrm{v}$ & 154 & 0.936 & 0.234 & WI $(\cap)$ & 34.0 & 積雪 (-) & 22.5 & 降水 $(n)$ & 19.8 & $\mathrm{CI}(\cap)$ & 16.4 & & \\
\hline & & 1 & 2 & ヤマボウシーブナ群集 & IV & 28 & 0.965 & 0.107 & 地質 (5) & 26.7 & $\mathrm{CI}(\cap)$ & 24.3 & 降水 $(+)$ & 21.2 & 積雪 $(n)$ & 16.2 & WI $(\cap)$ & 11.5 \\
\hline & $a_{1}$ & & 2 & クロモジーブナ群集 & IV & 46 & 0.983 & 0.102 & 降水 $(\Omega)$ & 45.0 & 積雪 $(n)$ & 20.8 & $\mathrm{CI}(\cap)$ & 13.7 & 地質 (5) & 9.3 & 傾斜 (+) & 7.1 \\
\hline & 11 & & $\sigma^{3}$ & コナラ群落 (V) & $\mathrm{V}$ & 31 & 0.972 & 0.248 & 降水 $(+)$ & 46.9 & $\mathrm{CI}(\cap)$ & 27.9 & WI $(\cap)$ & 9.2 & 地質 $(5,6,7)$ & 8.5 & & \\
\hline & & 2 & & イヌブナ群落 & IV & 25 & 0.974 & 0.217 & $\mathrm{CI}(\cap)$ & 24.9 & 傾斜 (+) & 17.9 & 積雪 $(\cap)$ & 17.5 & 地質 $(2,4,6)$ & 16.5 & 降水 $(\Omega)$ & 15.7 \\
\hline & & & & クリーコナラ群集 & VII & 202 & 0.917 & 0.216 & 積雪 $(-)$ & 31.1 & WI $(\cap)$ & 28.2 & $\mathrm{CI}(\mathrm{n})$ & 17.6 & 地質 $(4,6)$ & 8.5 & 傾斜 $(\cap)$ & 8.0 \\
\hline & & 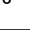 & & アカマツ群落 (V) & $\mathrm{v}$ & 97 & 0.910 & 0.265 & WI $(n)$ & 50.9 & CI $(n)$ & 21.9 & 積雪 $(-)$ & 11.5 & 降水 $(\cap)$ & 6.6 & & \\
\hline & & & & シラキーブナ群集 & IV & 72 & 0.985 & 0.088 & 積雪 $(-)$ & 40.2 & $\mathrm{CI}(\Omega)$ & 31.3 & 降水 $(\Omega)$ & 22.5 & & & & \\
\hline & 2 & 1 & & アカシデーイヌシデ群落(V) & $\mathrm{v}$ & 101 & 0.937 & 0.292 & 積雪 $(-)$ & 28.6 & $\mathrm{CI}(\cap)$ & 22.9 & 降水 $(+)$ & 21.6 & WI $(\cap)$ & 18.6 & 傾斜 (+) & 6.9 \\
\hline & & 2 & & |リヨウブーミズナラ群集 & IV & 25 & 0.937 & 0.205 & 降水 $(\Omega)$ & 45.5 & 積雪 (-) & 42.5 & 地質 (5) & 8.7 & & & & \\
\hline & & & & チシマザサーブナ群団 & IV & 91 & 0.928 & 0.331 & 積雪 $(+)$ & 39.2 & 降水 $(+)$ & 31.0 & WI $(\Omega)$ & 10.5 & 地質 $(2,5,7)$ & 9.1 & $\mathrm{CI}(\Omega)$ & 5.5 \\
\hline & 1 & 1 & & オオバクロモジーミズナラ群集 & $\mathrm{v}$ & 133 & 0.936 & 0.271 & 積雪 $(\cap)$ & 43.4 & $\mathrm{CI}(\cap)$ & 21.8 & 降水 (+) & 13.3 & 地質 (2) & 9.3 & WI $(\cap)$ & 9.0 \\
\hline & & 2 & & ブナニ次林 & $\mathrm{v}$ & 22 & 0.997 & 0.326 & 降水 (+) & 29.2 & 積雪 (+) & 24.0 & $\mathrm{CI}(\cap)$ & 21.2 & 地質 $(2,5)$ & 20.8 & & \\
\hline c & ? & & & オクチョウジザクラーコナラ群集 & $\mathrm{V}$ & 61 & 0.970 & 0.202 & 積雪 $(\cap)$ & 37.3 & WI $(\cap)$ & 37.0 & 降水 $(\cap)$ & 11.5 & 地質 (2) & 7.0 & & \\
\hline & $1^{2}$ & & & カスミザクラーコナラ群落 & $\mathrm{v}$ & 43 & 0.977 & 0.096 & 積雪 $(\cap)$ & 30.6 & WI $(\cap)$ & 25.2 & 地質 (1) & 12.8 & 傾斜 $(n)$ & 12.2 & 降水 $(\cap)$ & 10.1 \\
\hline & $3_{3}$ & & & ユキグニミツバツツジーアカマツ群集 & VII & 49 & 0.974 & 0.111 & 積雪 $(\cap)$ & 36.3 & $\mathrm{CI}(\cap)$ & 29.7 & WI $(\cap)$ & 13.6 & 降水 $(\cap)$ & 13.5 & & \\
\hline & 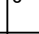 & & & ユキグニミツバツツジーコナラ群集 & $\mathrm{v}$ & 66 & 0.981 & 0.078 & 積雪 $(\cap)$ & 34.0 & $\mathrm{CI}(\cap)$ & 29.5 & WI $(\cap)$ & 15.6 & 降水 $(\cap)$ & 10.4 & 地質 (2) & 5.8 \\
\hline D & $1_{1}$ & & & キタコブシーミズナラ群集 & $\mathrm{V}$ & 30 & 0.994 & 0.251 & 地質 $(4,6)$ & 41.4 & $\mathrm{CI}(\cap)$ & 34.2 & 降水 $(\cap)$ & 14.9 & & & & \\
\hline 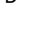 & 1 & & & ホソバヒカゲスゲーコナラ群集 & $\mathrm{v}$ & 34 & 0.989 & 0.247 & 地質 $(4,6)$ & 39.7 & $\mathrm{CI}(\cap)$ & 37.5 & 降水 $(n)$ & 14.7 & & & & \\
\hline & & & & シキミーモミ群集 & $\mathrm{VI}$ & 108 & 0.936 & 0.323 & \begin{tabular}{|l} 
積雪 $(-)$ \\
\end{tabular} & 41.6 & WI $(\cap)$ & 21.1 & 降水 $(+)$ & 12.9 & $\mathrm{CI}(\mathrm{n})$ & 11.2 & 地質 $(3,4)$ & 7.0 \\
\hline & & 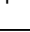 & & アカシデーイヌシデ群落 (VII) & VII & 24 & 0.927 & 0.240 & 積雪 $(-)$ & 29.7 & 地質 $(3,5,6,7)$ & 18.5 & 傾斜 (+) & 18.2 & CI $(\cap)$ & 16.7 & 降水 $(+)$ & 13.1 \\
\hline $\mathrm{E}$ & 1 & 2 & & アカガシ群落 & $\mathrm{VI}$ & 31 & 0.910 & 0.306 & 積雪 $(-)$ & 42.1 & 地質 $(3,5,6)$ & 22.9 & CI (-) & 17.4 & 傾斜 (+) & 11.0 & & \\
\hline 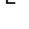 & & & & ウラジロガシ群落 & \begin{tabular}{|l|ll}
$\mathrm{VI}$ \\
\end{tabular} & 45 & 0.937 & 0.140 & WI $(\cap)$ & 29.1 & 傾斜 (+) & 25.3 & 地質 $(6,7)$ & 19.9 & $\mathrm{CI}(\cap)$ & 18.8 & & \\
\hline & & 3 & & アカガシニ次林 & VII & 29 & 0.981 & 0.194 & 積雪 $(-)$ & 36.7 & 降水 (+) & 30.6 & CI (-) & 14.8 & 地質 $(3,5)$ & 10.4 & & \\
\hline & 2 & & & イスノキーウラジロガシ群集 & \begin{tabular}{|l|ll}
$\mathrm{VI}$ \\
\end{tabular} & 41 & 0.976 & 0.251 & 積雪 $(-)$ & 40.0 & 降水 $(n)$ & 27.1 & 傾斜 $(n)$ & 13.6 & 地質 $(3,5)$ & 13.4 & & \\
\hline & & & 1 & シラカシ群集 & $\mathrm{VI}$ & 29 & 0.933 & 0.191 & 積雪(-) & 54.2 & $\mathrm{CI}(-)$ & 23.7 & 地質 (1) & 19.4 & & & & \\
\hline & & 1 & 1 & クヌギーコナラ群集 & VII & 96 & 0.966 & 0.304 & $\mathrm{CI}(-)$ & 49.6 & 積雪 (-) & 17.7 & WI $(\cap)$ & 11.0 & 降水 $(\cap)$ & 9.9 & 地質 (1) & 7.2 \\
\hline & & & 2 & ヤマツツジーアカマツ群集 & VII & 24 & 0.940 & 0.367 & 積雪(-) & 51.4 & CI (-) & 24.8 & 傾斜 (-) & 18.8 & & & & \\
\hline & & & 1 & カナメモチーコジイ群集 & $\mathrm{VI}$ & 132 & 0.933 & 0.317 & WI $(\cap)$ & 43.0 & 積雪 (-) & 34.2 & 降水 $(\cap)$ & 13.5 & & & & \\
\hline & & & & アラカシ群落 & $\mathrm{VI}$ & 113 & 0.932 & 0.244 & WI $(+)$ & 44.0 & 積雪 (-) & 30.6 & 傾斜 $(n)$ & 9.1 & 降水 $(\cap)$ & 6.7 & & \\
\hline & & & & |ルリミノキーイチイガシ群集 & $\mathrm{VI}$ & 25 & 0.949 & 0.133 & 積雪 $(-)$ & 56.1 & 地質 (3) & 19.0 & 降水 $(+)$ & 12.8 & CI (-) & 10.5 & & \\
\hline & 11 & & $\left.\right|^{2}$ & シイ·カシニ次林 & VII & 512 & 0.872 & 0.346 & $\mathrm{CI}(-)$ & 78.9 & 積雪 (-) & 4.9 & 傾斜 $(-)$ & 4.5 & WI $(n)$ & 4.1 & & \\
\hline & & 2 & 2 & コナラ群落 (VII) & VII & 364 & 0.875 & 0.337 & $\mathrm{CI}(-)$ & 61.9 & 地質 $(5,6,7)$ & 12.2 & 傾斜 $(n)$ & 9.0 & 降水 $(\cap)$ & 8.6 & & \\
\hline & & & & アカマツ群落 (VII) & VII & 289 & 0.888 & 0.315 & $\mathrm{CI}(-)$ & 51.0 & 地質 $(5,6,7)$ & 13.9 & WI $(\cap)$ & 11.2 & 降水 $(\cap)$ & 10.9 & 積雪 $(-)$ & 7.4 \\
\hline & & & 4 & アベマキーコナラ群集 & VII & 108 & 0.937 & 0.336 & 積雪 $(-)$ & 54.0 & 降水 $(-)$ & 12.6 & CI (-) & 12.4 & WI $(\Omega)$ & 9.6 & 傾斜 (+) & 6.0 \\
\hline$F$ & & & 4 & モチツツジーアカマツ群集 & VII & 119 & 0.916 & 0.297 & 積雪 $(-)$ & 50.8 & $\mathrm{CI}(-)$ & 17.0 & WI $(\cap)$ & 14.0 & 降水 $(+)$ & 8.6 & & \\
\hline & & & 5 & |ネズーアカマツ群落 & VII & 46 & 0.984 & 0.119 & 積雪 $(-)$ & 36.7 & 降水 $(\cap)$ & 26.0 & 地質 $(5,6)$ & 14.3 & $\mathrm{CI}(-)$ & 9.9 & 傾斜 $(n)$ & 8.0 \\
\hline & & & 1 & ヤブコウジースダジイ群集 & $\mathrm{VI}$ & 130 & 0.930 & 0.257 & $\mathrm{CI}(-)$ & 67.4 & 地質 (1.2) & 9.0 & WI $(\cap)$ & 7.9 & 降水 $(\cap)$ & 7.1 & & \\
\hline & & 1 & $\left.1\right|^{1}$ & イノデータブノキ群集 & $\mathrm{VI}$ & 55 & 0.968 & 0.202 & $\mathrm{CI}(-)$ & 65.5 & 傾斜 (-) & 19.9 & 積雪 (-) & 6.8 & & & & \\
\hline & & & 2 & オニシバリーコナラ群集 & VII & 39 & 0.983 & 0.152 & $\mathrm{CI}(-)$ & 62.4 & 地質 (1) & 12.4 & WI $(\cap)$ & 10.9 & 積雪 (-) & 8.4 & & \\
\hline & & & 2 & スダジイ群落 & $\mathrm{VI}$ & 98 & 0.954 & 0.153 & $\mathrm{CI}(-)$ & 31.8 & WI $(\cap)$ & 25.3 & 降水 $(\cap)$ & 17.9 & 積雪 (-) & 16.8 & & \\
\hline & 12 & & 1 & トベラーウバメガシ群集 & $\mathrm{VI}$ & 75 & 0.974 & 0.181 & $\mathrm{CI}(-)$ & 45.6 & 積雪 $(-)$ & 38.6 & 傾斜 (-) & 7.4 & & & & \\
\hline & ]$^{2}$ & & 1 & ウバメガシニ次林 & VII & 60 & 0.953 & 0.219 & 積雪 $(-)$ & 83.3 & 地質 $(3,7)$ & 8.0 & & & & & & \\
\hline & & & 2 & ホソバカナワラビースダジイ群集 & $\mathrm{VI}$ & 35 & 0.973 & 0.246 & $\mathrm{CI}(-)$ & 82.1 & 地質 $(2,3)$ & 12.5 & & & & & & \\
\hline & & 2 & 1 & ミミズバイースダジイ群集 & $\mathrm{VI}$ & 99 & 0.965 & 0.084 & $\mathrm{CI}(-)$ & 38.4 & 積雪 (-) & 32.6 & 降水 $(\cap)$ & 13.0 & WI $(\cap)$ & 11.8 & & \\
\hline & & & 2 & タブノキーヤブニッケイニ次林 & VII & 93 & 0.945 & 0.164 & $\mathrm{CI}(-)$ & 83.7 & 降水 $(\cap)$ & 9.5 & & & & & & \\
\hline & & & 2 & タブノキ群落 & \begin{tabular}{|l|l}
$\mathrm{VI}$ \\
\end{tabular} & 38 & 0.903 & 0.393 & $\mathrm{CI}(-)$ & 80.3 & 積雪 (-) & 9.9 & & & & & & \\
\hline
\end{tabular}

IV:ブナクラス域自然植生, V:ブナクラス域代償植生, VI: ヤ゙シツバキクラス域自然植生, VII: ヤブツバキクラス域代償植生 
の少ないところで分布確率が最大となる傾向を示し た. A2 は自然植生としてのカシワ群落（IV）と代 償植生としてのカシワ群落 (V) から構成されていた. 自然植生としてのカシワ群落（IV）は降水量が少な くなればなるほど, また, WI が小さいほど分布確 率が高くなっていた。一方, 代替植生としてのカシ ワ群落 (V) は CI が $20 \sim 50$ 程度の範囲で, かつ, 降水量が少ない地域での分布確率が最も高くなって いた。第四紀堆積岩から成る傾斜の緩やかな場所が 適地として選択されていることが，両者で共通して いる. 雨量が少なく涼しい地域での人為的な擋乱が, 乾燥に対する耐性が高いカシワ群落の分布拡大に寄 与したことを示唆している.これらのことにより, カシワ群落 (V) の潜在的分布域は中国地方にまで 広がったと考えられる。なお，環境省の植生図では, 明瞭な区分種をもたない場合は優占種名を用いた群 落名が与えられ, それが自然植生か代償植生かを気 候帯別に示寸ためローマ数字が付される（表 2).

Bのグループを構成する群集・群落は, 主に太平 洋側に潜在的な分布中心を持つブナ林とその代償植 生であった（図 1-B).ブナーミズナラ群落とクロモ ジーブナ群集を除き, このグループに属する群集・ 群落は, 最深積雪量の増加につれて分布確率が減少 した．B1 は東北地方から九州までの広い範囲に潜在 的な分布域を持つグループで, 自然植生であるヤマ ボウシーブナ群集は降水量が多い地域, クロモジー ブナ群集は $2500 \mathrm{~mm}$ 程度の降水量を持つ地域, イヌ ブナ群落は急傾斜で降水量が $1800 \mathrm{~mm}$ 程度の地域で 分布確率が最大となった. B2 を構成する自然植生の シラキーブナ群集は降水量が 2500 〜 $3000 \mathrm{~mm}$ 程度 で，リョウブーミズナラ群集は $2800 〜 3200 \mathrm{~mm}$ 程 度の地域で分布確率が最大となった。 B2 は, より湿 潤な地域に潜在的な分布域を持つグループだと言え る.

$\mathrm{C}$ は日本海側に潜在的な分布中心を持つグループ で (図 1-C), 主に最深積雪量によって潜在的な分布 域が規定された。 $\mathrm{C} 1$ に属する自然植生であるチシマ ザサーブナ群団は最深積雪量が $1 \mathrm{~m}$ を超える地域で, ブナ二次林は $1.7 \mathrm{~m}$ を超える地域で分布確率が最大 となった. C 2 を構成するオクチョウジザクラーコナ ラ群集は最深積雪量が $0.5 \sim 1.5 \mathrm{~m}$ 程度, カスミザ クラーコナラ群落は $0.5 \sim 0.8 \mathrm{~m}$ 程度の地域で分布 確率が最大となった. C3 に属するユキグニミツバッ ツジーアカマツ群集とユキグニミツバツツジーコナ ラ群集の分布確率は, 両者とも最深積雪量が $0.4 \sim 0.6$ $\mathrm{m}$ 程度の地域で最大となった. C2 と C 3 の潜在的な 分布の違いをもたらす環境要因は気温で, 前者はWI が $80 \sim 100$ 程度（CI は 15〜25 程度）の範囲で, 後者は CI が $5 \sim 10$ 程度, WI が $100 \sim 110$ 程度の範 囲で分布確率が最大となった.

Dのグループにはキタコブシーミズナラ群集およ びホソバヒカゲスゲーコナラ群集が属する. 両者の 潜在的分布域は局所的であり，互いに重なり合って いた（図 1-D). 他の群集・群落と異なり, 地質（火 山岩類, 古生代堆積岩類）が潜在的分布域の決定に 最も寄与する環境要因であった。環境省による植生 凡例解説によると, ホソバヒカゲスゲーコナラ群集 は, 北上半島南部から北上高地, 阿武隈高地にかけ ての火山灰に覆われた丘陵地, 低地に分布すると言 う (http://www.vegetation.jp/saikubun.php?kubun=220505). キタコブシーミズナラ群集は，ホソバヒカゲスゲー コナラ群集に比べて最大積雪深と CI 值が少しだけ大 きい傾向があったが，これら 2 者の潜在的な分布を 分ける環境要因は抽出できなかった.

$\mathrm{E}$ は東北太平洋岸から西日本にかけて潜在的分布 域を持つグループで (図 1-E), 自然植生としてのシ キミーモミ群集, アカガシ群落, ウラジロガシ群落, イスノキーウラジロガシ群集と, 代償植生としての アカシデーイヌシデ群落 (VII), アカガシ二次林が 含まれる。概して言うと, 中生代堆積岩地や深成岩 類 1 を含む地域で分布確率が高かった。そして, E1 は最大傾斜が急峻な地域ほど分布確率が高くなる傾 向を示し, E2 は最大傾斜が $30^{\circ}$ 程度の地域で分布 確率が最も高くなった。

$\mathrm{F}$ は関東以南に潜在的分布域の中心を持つグルー プで，互いに分布域は重なるものの，F1 は関東や中 国・瀬戸内地方に, F2 は関東地方以南の太平洋岸お よび中国地方の日本海沿岸に潜在的分布域が出現す る傾向があった（図 1-F)，F1 と F2ではWI が規定 要因として抽出されている群集・群落が多く, F1 で はWIが $100 〜 120$ 程度の地域で, F2では 120 を超 える地域で分布確率が最大となる傾向があった。F11 のシラカシ群集やクヌギーコナラ群集は, 関東平野 に分布中心があるが，それは，第四紀堆積岩類から 成る地域で分布確率が高くなることに対応してい た.

\section{2.「植生調査」データの活用に向けて}

本報告では,「植生調査」データに付加された植生 凡例を用いて空間モデルを構築することで, 分布確 
率に基づく潜在的分布域の推定や地図化を行うこと ができ, 分布を規定する環境要因を階層的に推定し ていける可能性があることを示した。ここで用いた 環境要因は物理環境にとどまっているが，植生デー 夕に記録されている個々の種の階層別植被率を用い ることで，標徴種や区分種をはじめとする個々の種 の分布特性といった生物的要因を加味した空間モデ ルへと発展させることも可能だろう.

本報告では, 潜在的分布域の空間重複性から群集・ 群落を類型化し，自然植生と代償植生との空間分布 の異同についても示した。例えば，チシマザサーブ ナ群団，オオバクロモジーミズナラ群集，ブナ二次 林，オクチョウジザクラーコナラ群集，ユキグニミ ツバツツジーアカマツ群集，ユキグニミツバツツジ ーコナラ群集の潜在的分布可能域は互いに類似する ものの, 最大積雪深や気温の違いによって好適地の 違いがもたらされていることが示された。これらは， 遷移系列を同じくする空間範囲の抽出と地図化の可 能性を示唆している，そして,それは第 2・3 回（1978 〜 1986 年度) の植生調査で作成された植生図との比 較や,「植生調査」データに記載されている種構成か ら検証可能だと思われる。遷移という時間軸をも考 慮した空間論への展開は, 挑戦すべきテーマだろう。 潜在的分布域図は，応用的な価值も持つ. 1999 年 から始まった植生図の再作成は，現在でも国土の 3 割程度が未作成となっている（http://www.vegetation. biodic.go.jp). そのため, 作業効率をあげつつ, 完成 を急ぐ必要がある，植生図が未作成となっている場 所の多くは，北海道や東北から中部地方にかけての 春梁地域に偏在している。 それは, 現地調查の遂行 に労力と費用がかかることが一つの要因となってい る. 未調査地域に分布する群集・群落やその分布境 界を推定し, 重点的に調査す心゙き地域を見出すこと で，効率的な調查設計と調査の遂行を助けることに なると思われる.

多くの努力と費用がかけられ蓄積されている「植 生調査」データには，植生学のみならず，空間生態 学や景観生態学に新たなテーマを提供し，学問的発 展をもたらすとても大きな価值を秘めている，そし て，自然環境保全法という法制度のもとで実施され ている「植生調査」は，世界にも誇り得るモニタリ ングの仕組みだと考えられる。この仕組が，将来に わたって継続されるよう, より多くの研究者が様々 な視点から「植生調查」データを活用し, 成果を生 み出していくことが期待される.

\section{謝辞}

本報告は，「平成 22 年度第 7 回 自然環境保全基礎 調查植生調查に係る技術専門部会（技術手法検討部 会）」に提供した資料（http://www.vegetation.biodic. go.jp/rikatsuyou/2-2.html）について, その詳細を解説 したものである. 解析・検討を進めるにあたって, 環境省自然環境局生物多様性センタ一から植生調査 データの提供を受けた。解析過程では，竹村紫苑氏 （総合地球環境学研究所）からご教示いただいた。ま た，原慶太郎氏（東京情報大学）を座長とする技術 専門部会の皆さまとの議論の過程で，示唆に富む助 言を得た。これらの方々に感謝する.

\section{引用文献}

Arakida, H., Mitsuhashi, H., Kamada, M. and Koyama, K. 2011. Mapping the potential distribution of shorebirds in Japan: the importance of landscape-level coastal geomorphology. Aquatic Conservation: Marine and Freshwater Ecosystems 21: 553-563.

ブラウン-ブランケ，J. 1964.（鈴木時夫訳，1971）植 物社会学 I. 359pp. 朝倉書店, 東京.

Elith, J., Graham, C.H., Anderson, R.P., Dudik, M., Ferrier, S., Guisan, A., Hijmans, R.J., Huettmann, F., Leathwick, J.R., Lehmann, Li, J., Lohmann, L.G., Loiselle, B.A., Manion, G., Moritz, C., Nakamura, M., Nakazawa, Y., Overton, Peterson, T., Phillips, S.J., Richardson, K., Scachetti-Pereira, R., Schapire, R.E., Soberón, J., Williams, S., Wisz, M.S. and Zimmermann, N.E. 2006. Novel methods improve prediction of species' distributions from occurrence data. Ecography 29: 129-151.

Fielding, A.H., and Bell, J.F. 1997. A review of methods for the assessment of prediction errors in conservation presence/absence models. Environmental Conservation 24: 38-49.

Franklin, J. 2010. Mapping Species Distributions: Spatial Inference and Prediction. 320pp. Cambridge University Press, Cambridge.

Hernandez, P.A., Graham, C.H., Master, L.L. and Albert, D.L. 2006. The effect of sample size and species characteristics on performance of different species distribution modeling methods. Ecography 29: 773-785. 
菊池多賀夫. 2001. 地形植生誌. $220 p p$. 東京大学出 版会, 東京.

Lui, C., White, M. and Newell, G. 2013. Selecting thresholds for the prediction of species occurrence with presence-only data. Journal of Biogeography 40: 778789.

Manel, S., Williams, H.C. and Ormerod, S.J. 2001. Evaluating presence-absence models in ecology: the need to account for prevalence. Journal of Applied Ecology 38: 921-931.

宮脇昭 - 奥田重俊 - 藤原陸夫 編. 1994. 改訂新版日 本植生便覧. 910pp. 至文堂, 東京.

Phillips, S.J., Anderson, R.P. and Schapire, R.E. 2006. Maximum entropy modeling of species geographic distribution. Ecological Modeling 190: 231-259.

Scott, J.M., Heglund, P.J., Morrison, M.L., Haufler, J.B., Raphael, M.G., Wall, W.A. and Samson, F.B. 2002. Predicting Species Occurrences: Issues of Accuracy and Scale. 868pp. Island Press, Washington.

染矢貴 - 竹村紫苑 - 宮本駿 - 鎌田磨人. 2010. 自然 環境情報 GIS と国土数值情報を用いた日本全域の 竹林分布と環境要因の推定. 景観生態学, 15: 4154.

Swets, J.A. 1988. Measuring the accuracy of diagnostic systems. Science 240: 1285-1293.

山中二男. 1979. 日本の森林植生, 補訂版. $223 p p$. 築地書館, 東京. 